\title{
Global Analysis of Genes Regulated by Low Temperature and Photoperiod in Peach Bark
}

\author{
Carole L. Bassett ${ }^{1,2}$, Michael E. Wisniewski², Timothy S. Artlip ${ }^{2}$, and John L. Norelli2 \\ USDA, ARS, Appalachian Fruit Research Station, 2217 Wiltshire Road, Kearneysville, WV 25430
}

Jenny Renaut
Centre de Recherche Public-Gabriel Lippmann, CREBS, 41 rue du Brill, L-4422 Belvaux, GD
Luxembourg

Robert E. Farrell, Jr. ${ }^{2}$

Department of Biology, Pennsylvania State University, 1031 Edgecomb Avenue, York, PA 17403

\begin{abstract}
ADDITIONAL INDEX wORDS. cold acclimation, short day photoperiod, night break, suppression subtractive hybridization, gene regulation, gene expression

ABSTRACT. In response to environmental cues plants undergo changes in gene expression that result in the up- or downregulation of specific genes. To identify genes in peach [Prunus persica $(\mathrm{L}$.$) Batsch.] trees whose transcript levels are$ specifically affected by low temperature (LT) or short day photoperiod (SD), we have created suppression subtractive hybridization (SSH) libraries from bark tissues sampled from trees kept at $5^{\circ} \mathrm{C}$ and $25^{\circ} \mathrm{C}$ under short day (SD) photoperiod or exposed to a night break (NB) interruption during the dark period of the SD cycle to simulate a long day (LD) photoperiod. Sequences expressed in forward and reverse subtractions using various subtracted combinations of temperature and photoperiod treatments were cloned, sequenced, and identified by BLAST and ClustalW analysis. Low temperature treatment resulted in the up-regulation of a number of cold-responsive and stress-related genes and suppression of genes involved in "housekeeping" functions (e.g., cell division and photosynthesis). Some stress-related genes not observed to be up-regulated under LT were increased in response to SD photoperiod treatments. Comparison of the patterns of expression as a consequence of different temperature and photoperiod treatments allowed us to determine the qualitative contribution of each treatment to the regulation of specific genes.
\end{abstract}

Organisms respond to environmental stress by exhibiting distinct changes in gene expression that confer varying levels of stress tolerance. The ability of plants to cold acclimate and develop freezing tolerance is especially critical. Early studies in Arabidopsis thaliana (L.) Heynh. identified several cold-regulated (COR) genes that were also responsive to drought (Baker et al., 1994; Shinozaki etal., 2003; Shinozaki and Yamaguchi-Shinozaki, 2000, Thomashow, 1998; Xin and Browse, 2000). It is recognized that genes associated with response to cold may overlap with drought-responsive genes because freezing stress is largely a dehydrative stress (Vertucci and Stushnoff, 1992).

More recent studies examining global gene regulation in response to LT have identified a number of genes that are coldregulated. For example, a recent microarray analysis of gene expression in A. thaliana identified some 306 genes responding to LT $\left(4^{\circ} \mathrm{C}\right)$, including 218 that were up-regulated at least 3 -fold by cold treatment (Fowler and Thomashow, 2002). In another study, serial analysis of gene expression (SAGE) in cold-treated leaves of A. thaliana indicated that 190 genes were up-regulated in response to LT, whereas 82 were repressed (Jung et al., 2003). There is considerable overlap in the genes identified as up- and

Received for publication 27 July 2005. Accepted for publication 6 Mar. 2006. The authors wish to thank Jami Young, Jennifer Sycalik, Sarah Riggleman, and Mia Brown for their expert technical assistance. We are grateful to Ann Callahan for many helpful discussions in analyzing the genes presented here. Mention of trade names or commercial products in this article is solely for the purpose of providing specific information and does not imply recommendation or endorsement by the U.S. Dept. of Agriculture. Supplemental material is available at http://www.ars. usda.gov/Research/docs.htm?docid=13462

'To whom reprint requests should be addressed. E-mail address: cbassett@afrs. ars.usda.gov

${ }^{2}$ These authors contributed equally to the design and execution of the experiments described in this paper. down-regulated in the two studies thus providing independent confirmation regarding sets of genes responding to LT.

Some global studies of stress responses have included multiple abiotic stresses or hormone treatments for comparison with cold exposure. For example, a total of 53 genes that were induced at least 5 -fold at $4{ }^{\circ} \mathrm{C}$ were identified from a microarray of $\approx 7000$ independent cDNAs (Seki et al., 2002) in A. thaliana; however, 22 of these genes were also expressed in response to drought and high salt. Likewise, in rice (Oryza sativa L.) an array of $\approx 1700$ cDNAs identified nine genes as being uniquely up-regulated at $4{ }^{\circ} \mathrm{C}$, compared to 27 genes that were induced by cold, drought, abscisic acid, or high salt (Rabbani et al., 2003). In another microarray approach, organ-specific gene expression was determined in A. thaliana roots and shoots in response to LT, mannitol, and salt stress (Kreps et al., 2002). Of $\approx 8100$ genes screened, only 42 were found to be unique to LT treatment in both roots and shoots and at either of two sampling times. In contrast, 118 genes responded to all three stresses.

A number of woody plant studies have been conducted to identify genes associated with cold acclimation and/or tolerance. Identification of genes associated with freezing tolerance using molecular mapping techniques has been attempted in blueberry (Vaccinium darrowi Camp x V. caesariense MacKenzie) (Arora et al., 2000), peach (Bliss et al., 2002), and Poncirus trifoliata (L.) Raf. (Cai et al., 1994). Seasonally expressed or cold-induced genes have been described in pubescent birch (Betula pubescens Ehrh.) (Rinne et al., 1998, 1999; Welling et al., 1997), blueberry (Muthalif and Rowland, 1994), sweet chestnut (Castanea sativa Mill.) (Lopez-Matas et al., 2004), P. trifoliata (Cai et al., 1995), red-osier dogwood (Cornus sericea L.) (Sarnighausen et al., 2002), mulberry (Morus bombycis Koidz.) (Ukaji et al., 1999, 2001), peach (Arora and Wisniewski, 1994; Artlip et al., 1997), 
several poplar species [Populus tremula (Dode) C.K.Schneid., P. tremula $\times$ P. tremuloides Michx., P. trichocarpa Torr. \& A. Gray] (Sterky et al., 2004), and rhododendron (Rhododendron catawbiense Michx.) (Marian et al., 2004; Wei et al., 2005). In many of these studies the genes up-regulated by LT were related to LEA- (late embryogenesis abundant) type proteins or small heat shock proteins.

Avariety of other gene products have also been associated with cold tolerance in both herbaceous and woody plants. For example, enzymes associated with the synthesis of compatible solutes have been shown to be more active and/or more abundant in response to LT (Kaplan and Guy, 2004; Schrader and Sauter, 2002). Likewise, accumulation of sugars and oligosaccharides corresponds with the development of freezing tolerance (Stushnoff et al., 1998). Changes in the abundance or identity of membrane-integral proteins and membrane-associated lipids are also often associated with cold responses (Kawamura and Uemura, 2003).

It has long been recognized that the development of cold acclimation in woody plants involves several stages (Fuchigami et al., 1970; Weiser, 1970). The first step reflects the tree's response to increasingly shorter days (SD photoperiods) resulting in the cessation of shoot growth and the onset of dormancy. This step is likely regulated primarily by phytochrome A (Howe et al., 1998; Olsen and Junttila, 2002; Welling et al., 2002). Later steps relate to changes in gene expression discussed above which result in proteins or substances that directly or indirectly protect the plant from subsequent LT extremes. This stage is achieved independently of SD acclimation, relying almost exclusively on LT induction (Welling et al., 2002). However, maximum cold hardiness generally results from a combination of both SD and LT exposure.

Induction of LT-responsive genes by light or SD exposure has been examined in several plants. Analysis of cor 15 a expression in A. thaliana indicated that light had little or no effect on mRNA abundance compared to LT (Kim et al., 2002). In barley (Hordeum vulgare L.), an acidic SK-like [S = having a serine tract, $\mathrm{K}=$ having one or more conserved lysine-rich motifs (Close, 1996)] dehydrin responded to SD at $4{ }^{\circ} \mathrm{C}$, but not LD at the same temperature (Fowler et al., 2001). In contrast, an acidic, SK-type dehydrin from pubescent birch responded primarily to LT with little change under SD or LD photoperiods, although a YK-type [Y = conserved DEYGNPmotif (Close, 1996)] dehydrin responded optimally to $\mathrm{SD}$, followed by LT treatment (Welling et al., 2004). Adehydrin-like, 24-kD protein from red-osier dogwood increased after trees were subjected to 8 weeks of SD treatment; however, accumulation of the dehydrin-like protein was preceded by a reduction in stem water content, making it unclear whether or not induction of the $24-\mathrm{kD}$ protein was due to SD or water deficit or both (Karlson et al., 2003).

Seasonal analysis of stress gene expression in peach has revealed that a $\mathrm{Y}_{2} \mathrm{~K}_{9}$-type dehydrin $(P p D h n 1)$ and a defensin $(P p$ $D f n 1)$ begin to accumulate in the fall, reaching maximum levels in November-December (Artlip et al., 1997; Wisniewski et al., 2003). Since accumulation of these mRNAs and polypeptides in the field parallels the transition to SD photoperiods, it has been nearly impossible to ascertain the relative contributions of photoperiod and LT to the induction of these genes. In the absence of oligoarray chips for temperate fruit crops and desiring to represent the whole mRNA population, including low abundant transcripts, we chose to use an improved SSH protocol (Diatchenko et al., 1996) coupled with growth of plant material under rigidly controlled conditions of light and temperature to begin addressing this question in peach trees. In this process sequences expressed by two populations of cDNA are subtracted, leaving behind an enriched population of differentially expressed cDNA sequences. This type of approach has not been reported for temperate tree fruit crops. Here we describe a series of experiments using SSH to examine the predominant signal regulating peach bark gene expression under different combinations of temperature $\left(5^{\circ} \mathrm{C}\right.$ vs. $25^{\circ} \mathrm{C}$ ) and photoperiod (SD vs. LD). The experiments were likewise designed to separate the photoperiod effects from the effects of temperature.

\section{Materials and Methods}

Tree Growth and EXPerimental Designs. Sixty 1-year-old, dormant peach seedlings of 'Canadian Harmony' on 'Tennessee Natural' rootstock (Adam's County Nursery, Aspers, Pa.) were planted in 10-L pots with equal volumes of Metromix 360 and supplemented with $30 \mathrm{~g}$ per pot Osmocote $17 \mathrm{~N}-2.6 \mathrm{P}-8.3 \mathrm{~K}$ fertilizer (Scotts, Marysville, Ohio) containing Mg (1\%), S (2.3\%) and trace elements (B, Cu, Fe, Mn, Mo, and $\mathrm{Zn},<0.5 \%$ ). Fertilizer release rates average $\approx 23 \%$ per month. In Spring 2002 , the trees were grown in a glasshouse under ambient conditions. Trees were watered daily, and re-fertilized after 2 months. At the conclusion of the various treatments, bark and leaves were harvested, frozen in liquid $\mathrm{N}_{2}$, and stored at $-80^{\circ} \mathrm{C}$. Several trees were harvested as time zero controls for the various treatments at the same time duplicate trees were placed in the growth chamber.

Photoperiod and temperature experiments were conducted as follows. Fourteen trees were placed within a growth chamber (CMP4030; Conviron, Winnipeg, Man., Canada) at either 5 or 25 ${ }^{\circ} \mathrm{C}$, with $8 \mathrm{~h}$ light/16 h dark cycles. Photosynthetic photon flux density was $\approx 500 \mu \mathrm{mol} \cdot \mathrm{m}^{-2} \cdot \mathrm{s}^{-1}$. The trees were divided into two groups, and placed within two boxes that were constructed within the chamber. The two boxes were open at the bottom and top to allow proper air flow, but the sides were enclosed. A long-day photoperiod was simulated by introducing a 15-min night break (four 150-W incandescent bulbs) into one of the boxes within the growth chamber $\approx 8 \mathrm{~h}$ into the dark cycle (Zhu and Coleman, 2001). Light impermeable coverings were placed over both boxes preventing light from the night break disrupting the short-day entrainment of the trees in the other box. Trees were subjected to these photoperiods and temperatures for 5 weeks (Table 1). Due to limited chamber space and experimental demands, the temperature treatments were separated by 8 weeks. Control trees for each temperature regimen were harvested from the pool of glasshouse trees at the respective zero time points (Table 1, $\mathrm{T}=0$ : cDNAs 5 and 6). To assess the efficacy of the photoperiod treatments, shoot growth was monitored by measuring branch length and bud set on the trees exposed to different temperatures and photoperiods (data not shown).

RNA ISOlATION AND CDNA SYNTHESIS. Peach bark tissues were prepared and RNA was extracted as per Artlip et al. (1997). cDNA synthesis was performed using the Super SMART system (Clontech, Palo Alto, Calif.) according to the manufacturer's directions. Seven-hundred nanograms total RNA were used for cDNA synthesis and the reaction products were separated in $2 \%$ agarose gels and visualized with SYBRGold (Molecular Probes, Eugene, Ore.) in a STORM 860 fluorescence image analyzer (GE Healthcare, Piscataway, N.J.). cDNAs from the various treatments are summarized in Table 1.

CDNA subtractive hybridization and suppression PCR. Subtractions of various treatment combinations are summarized 
Table 1. List of peach tree treatments and sampling times for RNA extraction from bark and subsequent cDNA synthesis.

\begin{tabular}{|c|c|c|c|c|c|c|}
\hline & \multicolumn{6}{|c|}{ cDNA no. } \\
\hline & 1 & 2 & 3 & 4 & $5^{2}$ & $6^{y}$ \\
\hline $\begin{array}{l}\text { Age difference } \\
\text { at sampling }{ }^{\mathrm{x}}\end{array}$ & 13 weeks & 13 weeks & 5 weeks & 5 weeks & 8 weeks & 0 \\
\hline Photoperiod & $\mathrm{SD}^{\mathrm{w}}$ & $\mathrm{NB}^{\mathrm{w}}$ & $\mathrm{SD}$ & NB & $\mathrm{LD}^{\mathrm{w}, \mathrm{v}}$ & $\mathrm{LD}^{\mathrm{v}}$ \\
\hline Temperature & $5^{\circ} \mathrm{C}$ & $5^{\circ} \mathrm{C}$ & $25^{\circ} \mathrm{C}$ & $25^{\circ} \mathrm{C}$ & $25^{\circ} \mathrm{C}$ & $25^{\circ} \mathrm{C}$ \\
\hline Sampling time ${ }^{u}$ & 5 weeks & 5weeks & 5 weeks & 5 weeks & $\mathrm{T}=0$ & $\mathrm{~T}=0$ \\
\hline $\begin{array}{l}{ }^{\mathrm{Z}} \mathrm{T}=0 \text { : Time } 0 \text { col } \\
{ }^{\circ} \mathrm{C} \text {. } \\
{ }^{\mathrm{y}} \mathrm{T}=0 \text { : Time } 0 \text { cor } \\
{ }^{\circ} \mathrm{C} \text {. } \\
{ }^{\mathrm{x}} \text { Age difference } \mathrm{r} \\
\text { when the } \mathrm{T}=0 \text { co } \\
\text { weeks), the begi } \\
\text { second experime } \\
{ }^{\mathrm{w}} \mathrm{SD}=\text { short day, } \\
{ }^{\mathrm{v}} \text { Trees were grow } \\
{ }^{\mathrm{u}} \text { Sample times ar }\end{array}$ & $\begin{array}{l}\text { ol for } 5{ }^{\circ} \mathrm{C} \\
\text { ol for } 25^{\circ} \mathrm{C} \\
\text { ects the lens } \\
\text { ol was sam } \\
\text { ing of the se } \\
5 \text { weeks lat } \\
=\text { long da } \\
\text { and kept in } \\
\text { neasured fro }\end{array}$ & $\begin{array}{l}\text { owth chamb } \\
\text { of the cham } \\
\text { d and the se } \\
\text { nd }\left(5^{\circ} \mathrm{C}\right) \\
\text { [a total of } 1 \\
\text { greenhouse } \\
\text { e greenhous } \\
\text { the time tr }\end{array}$ & $\begin{array}{l}\text { r experime } \\
\text { en the beg } \\
\text { pling dates } \\
\text { periment ( } \\
\text { weeks }(5+ \\
\mathrm{NB}=\text { nigh } \\
\text { under natu } \\
\text { s were mov }\end{array}$ & $\begin{array}{l}\text { greenhous } \\
\text { ing of the } f \\
\text { the end of } \\
\text { ), and sam } \\
\text { from the } 2 \\
\text { reak. } \\
\text { light. } \\
\text { to the gro }\end{array}$ & $\begin{array}{l}\text { emperatu } \\
\mathrm{t}\left(25^{\circ} \mathrm{C}\right) \\
\text { e first exp } \\
\text { ing at the } \\
{ }^{\circ} \mathrm{C} \mathrm{T}=0 \mathrm{sa}\end{array}$ & $\begin{array}{l}\text { was } \approx 25 \\
\text { was } \approx 25 \\
\text { eriment } \\
\text { iment (5 } \\
\text { d of the } \\
\text { ple]. }\end{array}$ \\
\hline
\end{tabular}

in Table 2. Amplification of cDNAs and suppression subtractive hybridization (Diatchenko et al., 1996) followed procedures outlined in the manufacturer's protocol (Clontech). Briefly, the cDNAs amplified by the Super SMART cDNA protocol were digested with RsaI, and a portion (the tester cDNA) of each cDNA was ligated separately to two different adaptors provided by the manufacturer. The remaining unligated cDNA served as driver in subsequent reactions. Two rounds of hybridization were performed, one with each tester + driver for each ligated adaptor separately, followed by a second hybridization after mixing the two hybridized samples together and adding more freshly denatured driver.

Cloning and analysis of PCR products. Two rounds of PCR following the manufacturer's protocol were performed at the conclusion of the last hybridization, a primary and secondary (nested primers) reaction. Products from the secondary (and sometimes from the primary) reactions were TOPO-cloned into pCR2.1 (Invitrogen, Carlsbad, Calif.) following the manufacturer's protocol. White colonies were isolated from selective media and analyzed by colony PCR using M13 forward and reverse primers to estimate insert sizes in the recombinant plasmids. Recombinant plasmids with inserts $>200$ bp were isolated with the QIAprep Spin Miniprep kit (Qiagen, Valencia, Calif.). These DNAs were sequenced in both directions using nested PCR primer 1 (5'-TCGAGCGGCCGCCCGGGCAGGT-3') and nestedPCR primer $2 \mathrm{R}$ (5'-AGCGTGGTCGCGGCCGAGGT-3') supplied by Clontech or using M13 forward and reverse primers. Sequencing was done by Macrogen (Seoul, South Korea) or by the Nucleic Acid Facility at the U.S. Dept. of Agriculture, Agricultural Research Service Eastern Regional Research Center (Wyndmoor, Pa.).

Vector, adaptor and primer sequences were initially trimmed by Chromas (Technelysium, Tewantin, Queensland, Australia) or by visual inspection, and finally checked by BLAST (Altschul et al., 1997) analysis in VecScreen (National Center for Biotechnology Information, Bethesda, Md.). Trimmed sequences were all BLASTed against the nr (nonredundant) protein database using BLASTx default parameters, and each match alignment was inspected visually if the lowest E value were above 0.001 or if the highest S score (bit score) were below 200. Sequences without similarity to entries in the protein database were BLASTed against the translated $\mathrm{db}$ (tBLASTx), re-examined at the nucleotide level using BLASTn or BLASTed against the Genome Database for Rosaceae [GDR (Clemson Univ., Clemson, S.C.)]. Select sequences or their conceptual translations were further characterized by ClustalW, PROSITE, PYMOOD (Allometra, Davis, Calif.), or at the Baylor College of Medicine (BCM) Search Launcher (Sequence Utilities) (Smith et al., 1996).

CONFIRMATION OF SUPPRESSION SUBTRACTIVE HYBRIDIZATION RESULTS. A portion of the cDNAs synthesized as described above were set aside for subtraction confirmation after PCR-select amplification and before $R s a \mathrm{I}$ digestion. These cDNAs were used as templates in touchdown PCR reactions. The primer pairs for each gene analyzed are shown in Table 3 . Primers and different dilutions of template cDNA were added to the PCR mix [Advantage 2 (Clontech) or HotStart (Qiagen)] according to the manufacturer's recommendations. Cycling parameters for touchdown PCR were: $1 \mathrm{~min}$ at $94{ }^{\circ} \mathrm{C}$, followed by 20 cycles of $30 \mathrm{~s}$ at $94{ }^{\circ} \mathrm{C}, 30 \mathrm{~s}$ at $\mathrm{Tm}+10^{\circ} \mathrm{C}^{*}, 1 \mathrm{~min}$ at $72{ }^{\circ} \mathrm{C}$ and 15 cycles of $30 \mathrm{~s}$ at $94^{\circ} \mathrm{C}, 30 \mathrm{~s}$ at the $\mathrm{Tm}, 1 \mathrm{~min}$ at $72^{\circ} \mathrm{C}$. The asterisk indicates that the annealing temperature was decreased by $0.5^{\circ} \mathrm{C}$ each cycle to a final annealing temperature equal to the manufacturer's highest predicted Tm of each primer pair (Qiagen). Ten microliters (one-half the reaction volume/lane) were loaded into the wells of a $1 \%$ to $3 \%$ agarose gel and electrophoresed as previously described. Bands were visualized as before. Products from template dilutions indicating that the reactions were still in the linear phase were chosen for quantitation with digital image software [ImageQuant (GE Healthcare) or Gel-Pro Analyzer (Media Cybernetics, Silver Spring, Md.)].

\section{Results}

GLOBAL ANALYSIS. cDNA libraries were constructed from bark tissues of peach trees subjected to $25^{\circ} \mathrm{C}$ or $5^{\circ} \mathrm{C}$ and either SD $(8$ $\mathrm{h}$ light/16 h dark) photoperiods or a NB interruption to simulate a long day photoperiod (Zhu and Coleman, 2001) (Table 1). These libraries were utilized in different combinations of SSH to identify up- and down-regulated genes responding to the temperature and photoperiod treatments (Table 2). A control subtraction between cDNAs 5 and 6 revealed only three genes that reflected any "age" differences ( 8 weeks) between the $25^{\circ} \mathrm{C}$ and $5^{\circ} \mathrm{C}$ experiments (data not shown). These genes were subsequently removed from 
Table 2. Summary of subtraction combinations used with cDNAs synthesized from the RNAs sampled from peach trees treated with various combinations of temperature and photoperiod.

\begin{tabular}{|c|c|c|c|}
\hline Tester cDNA & Driver cDNA & Designation & Putative difference \\
\hline cDNA 5 & cDNA 2 & A Forward (AF) & $25^{\circ} \mathrm{C}$ vs $5{ }^{\circ} \mathrm{C}+[\mathrm{LD} / \mathrm{NB}]$ \\
\hline $25^{\circ} \mathrm{C} \mathrm{GH}^{\mathrm{Z}}$ control & $\mathrm{NB}$ at $5{ }^{\circ} \mathrm{C}$ & & \\
\hline cDNA 2 & cDNA 5 & A Reverse (AR) & \\
\hline $\mathrm{NB}$ at $5{ }^{\circ} \mathrm{C}$ & $25^{\circ} \mathrm{C} \mathrm{GH}$ control & & \\
\hline cDNA 6 & cDNA 3 & B Forward (BF) & LD vs $\mathrm{SD}^{\mathrm{y}}$ \\
\hline $25^{\circ} \mathrm{C} \mathrm{GH}$ control & $\mathrm{SD}$ at $25^{\circ} \mathrm{C}$ & & \\
\hline cDNA 3 & cDNA 6 & B Reverse (BR) & \\
\hline $\mathrm{SD}$ at $25^{\circ} \mathrm{C}$ & $25^{\circ} \mathrm{C} \mathrm{GH}$ control & & \\
\hline cDNA 2 & cDNA 1 & C Forward (CF) & NB vs $\mathrm{SD}^{\mathrm{x}}$ \\
\hline $\mathrm{NB}$ at $5{ }^{\circ} \mathrm{C}$ & $\mathrm{SD}$ at $5{ }^{\circ} \mathrm{C}$ & & \\
\hline cDNA 1 & cDNA 2 & C Reverse (CR) & \\
\hline $\mathrm{SD}$ at $5{ }^{\circ} \mathrm{C}$ & $\mathrm{NB}$ at $5{ }^{\circ} \mathrm{C}$ & & \\
\hline cDNA1 & cDNA 3 & E Forward (EF) & $5^{\circ} \mathrm{C}$ vs $25^{\circ} \mathrm{C}$ \\
\hline $\mathrm{SD}$ at $5{ }^{\circ} \mathrm{C}$ & $\mathrm{SD}$ at $25^{\circ} \mathrm{C}$ & & \\
\hline cDNA 3 & cDNA1 & E Reverse (ER) & \\
\hline $\mathrm{SD}$ at $25^{\circ} \mathrm{C}$ & $\mathrm{SD}$ at $5{ }^{\circ} \mathrm{C}$ & & \\
\hline cDNA 5 & cDNA6 & L Forward (LF) & $\operatorname{Age}^{\mathrm{w}}$ \\
\hline $25^{\circ} \mathrm{C} \mathrm{GH}$ control & $25^{\circ} \mathrm{C} \mathrm{GH}$ control & & \\
\hline cDNA 6 & cDNA5 & L Reverse (LR) & \\
\hline $25^{\circ} \mathrm{C} \mathrm{GH}$ control & $25^{\circ} \mathrm{C} \mathrm{GH}$ control & & \\
\hline \multicolumn{4}{|c|}{ 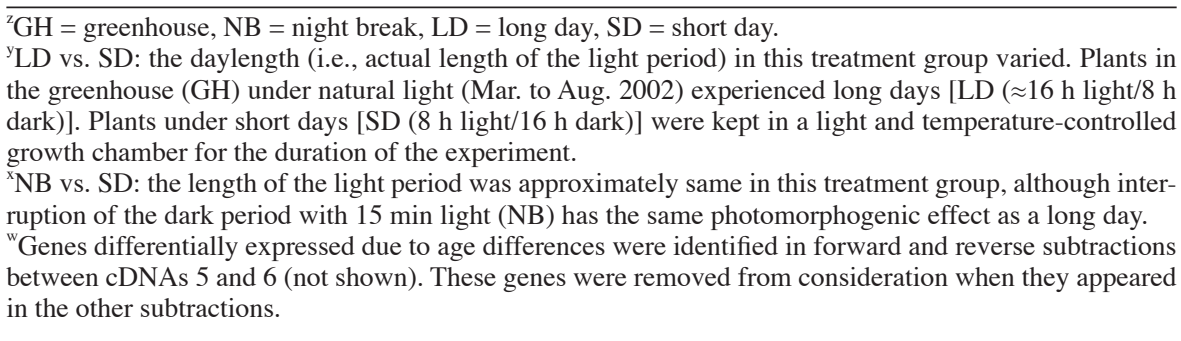 } \\
\hline
\end{tabular}

Table 3. List of peach primers used to assess expression of select genes by reverse transcription PCR.

\begin{tabular}{|c|c|c|}
\hline Select gene & Forward primer & Reverse primer \\
\hline $\mathrm{T}-\mathrm{C}^{\mathrm{z}}$ tumor protein & 5'-TCTCСТCТСААТСССТАGTAAАTCT-3' & 5'ATCTTCCСCACCACCTTCAG-3' \\
\hline PpDhn3 & 5'-TCGGGGCTTGTTTGATTTCCTG-3' & 5'-TGGGCTCGCAACCTACACCTG-3' \\
\hline Class IV chitinase & 5'-AAGACTGCCCTGTGGTTTTG-3' & 5'-TGCGCTAGCTTTTTATTTTATTTA-3' \\
\hline $\mathrm{PC}^{\mathrm{y}}$ protein-like gene & 5'-TTTCAAGTGCTTTCCTCCAGTTTC-3' & 5’-GCCGCTTGCATTGTTTCCTT-3' \\
\hline LEA $^{\mathrm{x}}$-like gene & 5'-GGCAACTTCACCATACCACTT-3' & 5'-AGATAACAACCAGCTGAAAACAAA-3' \\
\hline 14-3-3-like gene & 5'-GCCGAGCGCTACGAAGAGATG-3' & 5'-TGGCGGAGGGCACGAGATT-3’’ \\
\hline $\mathrm{LTP}^{\mathrm{w}}$ & 5'-CCGTGACCGCCCCGAACC-3' & 5'-CTAGCAATTGGCAGGATGAGGAAG-3 \\
\hline Class II chitinase & $5^{\prime}$-GCCACGCCCACATTCAAG-3' & 5'-ATCCAACTCACGCACAACTACAAC-3' \\
\hline
\end{tabular}

consideration in the analyses of subtraction combinations. Figure 1 illustrates typical results from several subtracted combinations. The banding patterns within a subtraction (e.g., AF vs. AR) are very different, as are the patterns between subtractions (cf. AF and BF). These bands were individually cloned and sequenced, resulting in the identification of a total of some 180 individual genes represented in 291 clones. Confirmation of the efficacy of subtracted hybridization was obtained by PCR analysis of
cDNAs prior to subtraction using primer pairs for select genes, as illustrated in Figs. 2 and 3 and in Table 4.

Sequences identified by BLAST analyses were analyzed using PYMOOD software, as well as by visual inspection, to determine overlap between the A-E subtractions. The results of these analyses are shown in Tables 5 and 6 and summarized in Fig. 4. In the subtracted combinations there were two subtractions that differed by temperature treatment (A and E) and two 


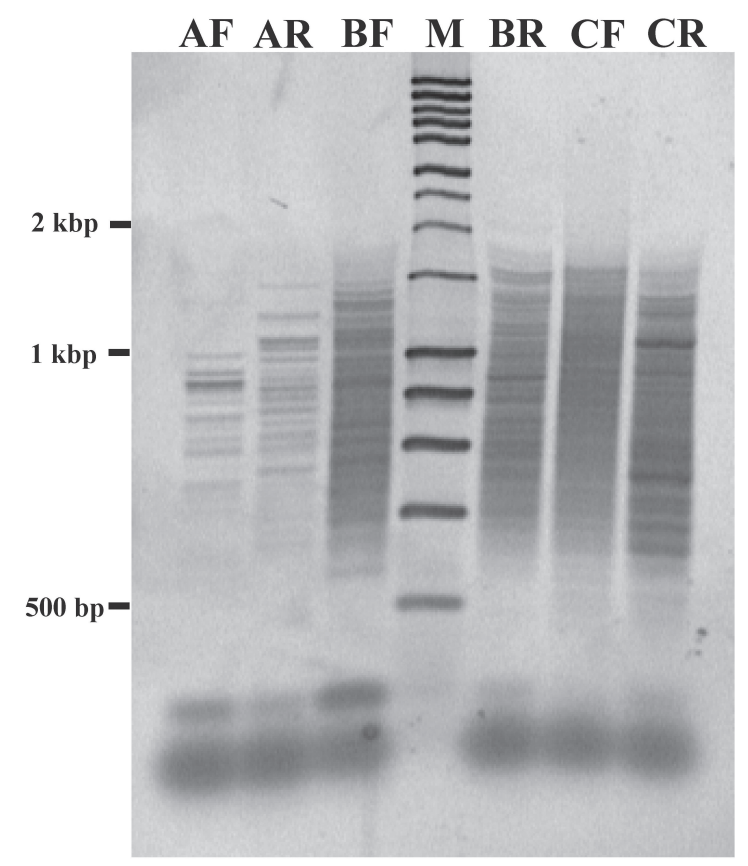

Fig. 1. PCR products from peach subtracted cDNA combinations representing sequences up- or down-regulated by low temperature $\left(5^{\circ} \mathrm{C}\right)$ or short day photoperiods ( $8 \mathrm{~h}$ light/16h dark). cDNAs subtracted and amplified as described in Materials and Methods were separated in 2\% agarose gels and visualized by SYBR Gold staining. Molecular mass markers $(\mathrm{M})$ are indicated in base pairs (bp) to the left of the gel ( $\mathrm{kbp}=$ kilobase pairs). $\mathrm{AF}=$ forward subtraction of cDNAs 5 (tester) and 2 (driver), AR = reverse subtraction of cDNAs 2 (tester) and 5 (driver), $\mathrm{BF}=$ forward subtraction of cDNAs 6 (tester) and 3 (driver), $\mathrm{BR}=$ reverse subtraction of cDNAs 3 (tester) and 6 (driver), $\mathrm{CF}=$ forward subtraction of cDNAs 2 (tester) and 1 (driver), $\mathrm{CR}=$ reverse subtraction of cDNAs 1 (tester) and 2 (driver). that differed by photoperiod (B and C). As indicated in Fig. 4, there are several LT up-regulated genes that overlap between the A and E subtractions, but only one gene down-regulated in common. Likewise, there are also overlapping genes up- and down-regulated by SD treatments (B and C). Interestingly, there were only 10 genes regulated by both SD and LT. The majority of genes isolated were unique to a given treatment [supplemental Tables 1-8 (see footnote "3" on p. 1)].

ANALysis of SELECT Genes. More detailed analyses of genes predominantly regulated by LT or SD are shown in Tables 4 and 5 , respectively. A disproportionately large number of defenserelated genes are increased in response to $\mathrm{LT}$ and $\mathrm{SD}$, although $\beta$-1,3-glucanase was the only gene observed to be up-regulated by both LT and SD (Fig. 4). Likewise, most of the LT or SD down-regulated genes appear to be associated with housekeeping functions, such as general metabolism and cell division. More genes related to fatty acid and energy metabolism responded to $\mathrm{SD}$ than to LT treatment.

Four genes not previously identified in any study as being responsive to LT were shown to be up-regulated at $5{ }^{\circ} \mathrm{C}$. These included a transducin-like protein, which may be related to G-coupled signaling, a putative mRNA binding protein, and a TAR1-like protein of unknown function first described in yeast (Coelho et al., 2002). The fourth novel gene up-regulated by LT is a peach dehydrin, $P p D h n 3$. This gene encodes an $\mathrm{SK}_{2}$-type polypeptide with at least one degenerate D-like segment and is most closely related to dehydrins from poplar and silver birch (Fig. 5) rather than to PPDHN2, a structurally similar $\mathrm{Y}_{2} \mathrm{SK}_{3}$-type peach dehydrin. Surprisingly, the conceptually translated product, PPDHN3, is predicted to contain four cysteines. Furthermore, PPDHN3 is also significantly different from PPDHN1 $\left(\mathrm{Y}_{2} \mathrm{~K}_{9}\right)$ in size, as well as sequence (not shown). A partial clone of PpDhnl was isolated from the EF (cold responsive) subtracted library,

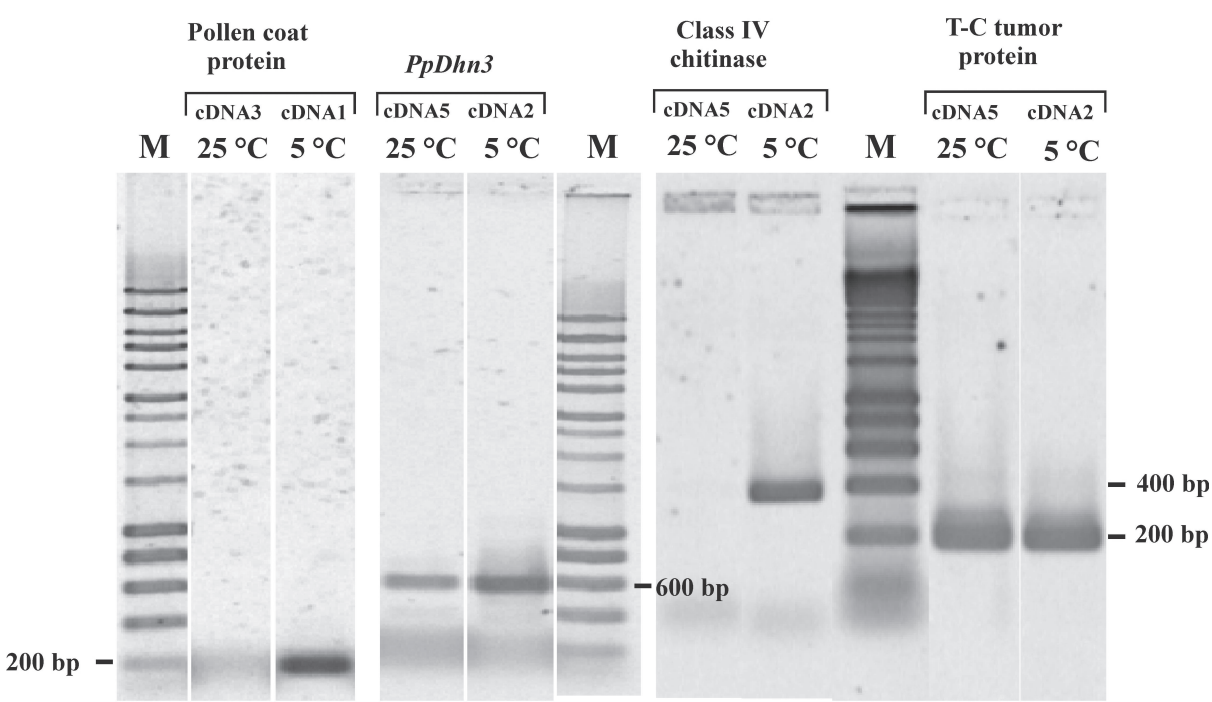

Fig. 2. Semi-quantitative reverse transcription PCR confirmation of subtractions A and E using RNA from the bark of peach trees exposed to $5^{\circ} \mathrm{C}$ or $25^{\circ} \mathrm{C}$ to synthesize cDNA (Table 1). PCR products were generated from aliquots of template cDNAs $1,2,3$ and 5 removed prior to subtraction as detailed in Materials and Methods. Specific primers for the following genes were used with optimal dilutions of each appropriate template cDNA: pollen coat protein-like gene (from the EF subtraction representing LT up-regulation), peach dehydrin 3 (from the AR subtraction representing LT up-regulation), class IV chitinase (from the AR subtraction) and the translationally controlled (T-C) tumor protein (from the AF subtraction representing LT down-regulation). The products were separated in agarose gels and visualized as described in the legend to Fig. 1. Molecular mass markers (M) are indicated in base pairs to the left and right of the gels. whereas PpDhn3 was found in the cold responsive AR subtracted library.

The TAR1-like sequence (EF49-02) also from the cold responsive $\mathrm{EF}$ subtracted library was a short, but good quality match to the yeast TAR1 (transcript antisense to ribosomal RNA) protein $(\operatorname{tar} 1 \mathrm{p})$. However, longer matches were obtained with sequences from a rice chromosomal library and a variety of dicot ESTs, including several peach sequences (Fig. 6). Two translation frames for EF49-02 and the plant sequences were equally good; however, only one frame matched any known sequences (i.e., $\operatorname{tar} 1 \mathrm{p}$ ).

The LT-responsive transducin-like protein had strong similarity to two transducinlike A. thaliana proteins (data not shown), but only weak similarity to the WD-40 repeat motif associated with such proteins. In addition, this clone represented only about one-third of the carboxyterminal end, and, as a result, any potential upstream consensus WD-40 repeats were not visible. It is not clear whether these proteins function like classical transducins or like other WD-40 repeat proteins, which function in a variety of roles where protein-protein interactions are important. 

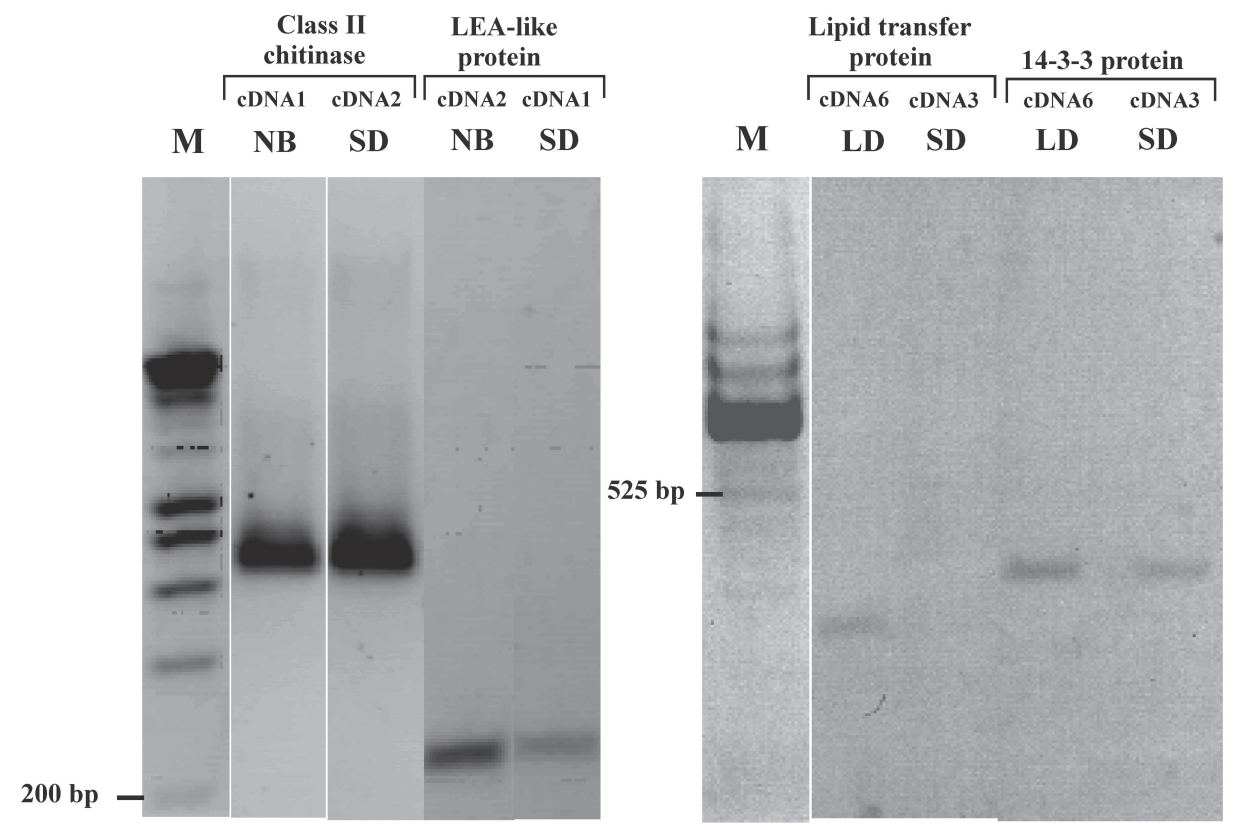

Fig. 3. Semi-quantitative reverse transcription PCR confirmation of subtractions B and C using RNA from the bark of peach trees exposed to different photoperiods to synthesize cDNA. PCR products were generated from aliquots of cDNAs 1,2, 3, and 6 removed before subtraction using specific primers for the following genes: class II chitinase (from the CR subtraction representing SD up-regulation), late-embryogenesis-abundant (LEA)-like protein (from the CF subtraction representing SD down-regulation), non-specific lipid transfer protein (from the BF subtraction representing SD down-regulation) and a 14-3-3 protein (from the $\mathrm{BF}$ subtraction). The products were separated in agarose gels and visualized as described in the legend to Fig. 1. Molecular mass markers (M) are indicated in base pairs to the left of the gels). $\mathrm{SD}=$ short days $(8 \mathrm{~h}$ light $/ 16 \mathrm{~h}$ dark), $\mathrm{LD}=$ long days (greenhouse under natural light), $\mathrm{NB}=$ night break $(15 \mathrm{~min}$ light given 8 $\mathrm{h}$ into the dark period of SD-exposed plants).

Table 4. Changes (fold difference) in expression of randomly selected peach genes in response to low temperature or short day treatments to confirm subtractions.

\begin{tabular}{lccc}
\hline & \multicolumn{2}{c}{$\begin{array}{c}\text { Change } \\
\text { (increase or decrease) }\end{array}$} \\
\cline { 2 - 3 } Gene & $5^{\circ} \mathrm{C}$ & SD $^{\mathrm{y}}$ & \\
Fold difference \\
\hline PpDhn3 & $>$ & & 2.5 \\
PC ${ }^{\mathrm{z}}$ protein-like gene & $>$ & & 5.9 \\
Class IV chitinase & $>$ & & 266.0 \\
Lipid transfer protein & & $<$ & -7.1 \\
LEA ${ }^{\mathrm{w}}$-like protein & & $<$ & -2.2 \\
14-3-3 protein & & $<$ & -2.0 \\
T-C ${ }^{\mathrm{v}}$ tumor protein & $<$ & & -1.1 \\
Class II chitinase & & $>$ & 1.4 \\
\hline
\end{tabular}

${ }^{\overline{\mathrm{z}}}$ Ten-fold dilutions of the various cDNA templates were used to determine optimal PCR conditions for quantitation, as described in Materials and Methods. Bands of PCR products from reactions in the linear phase of the amplification curve were quantified with digital imaging analysis software to compute fold change in expression.

${ }^{\mathrm{y}} \mathrm{SD}=$ short day $(8 \mathrm{~h}$ light $/ 16 \mathrm{~h}$ dark $)$.

${ }^{x} \mathrm{PC}=$ pollen coat.

${ }^{\mathrm{w}} \mathrm{LEA}=$ late embryogenesis abundant.

${ }^{\mathrm{v}} \mathrm{T}-\mathrm{C}=$ translationally controlled.

Previous studies have identified several genes associated with RNA regulation and metabolism that respond to LT treatment (Gong et al., 2002; Karlson et al., 2002). One of the clones isolated from the EF cold up-regulated subtracted library had strong similarity to a putative RNA binding protein from fava bean (Vicia faba L.) (Fig. 7). Although the fava bean gene was originally designated as a possible transcription factor, it appears to be homologous to a novel class of RNA binding genes (Landsberger et al., 2002).

\section{Discussion}

Studies in A. thaliana analyzing global regulation of genes in response to LT have identified a number of genes showing differential expression. In these studies, as in the present one, the majority of genes up-regulated in LT were previously identified as cold responsive, although some were also associated with responses to other abiotic or biotic stresses (Fowler and Thomashow, 2002; Jung et al., 2003; Kreps et al., 2002; Seki et al., 2001, 2002). Among those genes responding primarily to cold treatment in two or more studies were Xero2 (a homologue of PpDhn1), several LEA/Cor/ERD genes, $\beta$-amylase, and several light-inducible proteins. Although some of the studies identified a cold-responsive type II dehydrin (Fowler and Thomashow, 2002; Jung et al., 2003), none of the studies found Xerol to be LT regulated within the limitations of the experimental design and/or methodology. In the present study we identified a new type II peach dehydrin similar to Blti36 and Cor47 which was LT-responsive. We also did not find the peach Xerol homologue (PpDhn2) in any of the subtracted cDNA combinations, consistent with the observation that it is primarily regulated by water deficit stress (Wisniewski et al., 2006).

Based on data reported from previous A. thaliana studies, several conclusions can be drawn: 1) a number of genes induced by LT are also induced by other stresses (see also Rabbani et al., $2003), 2$ ) only a few genes are uniquely responsive to cold treatment, and 3) in general, more genes appear to be repressed, than induced by LT treatment (see also Wei et al., 2005). Our results likewise support these observations using a different methodology to obtain genes differentially regulated by LT. In addition we discovered two genes, $P p D h n 3$ and TAR 1 , not previously reported that are up-regulated primarily by LT compared to photoperiod. We also found two previously identified genes whose expression had not been linked to any specific biological process. The trans- 
Table 5. List of peach bark sequences regulated predominantly by cold treatment

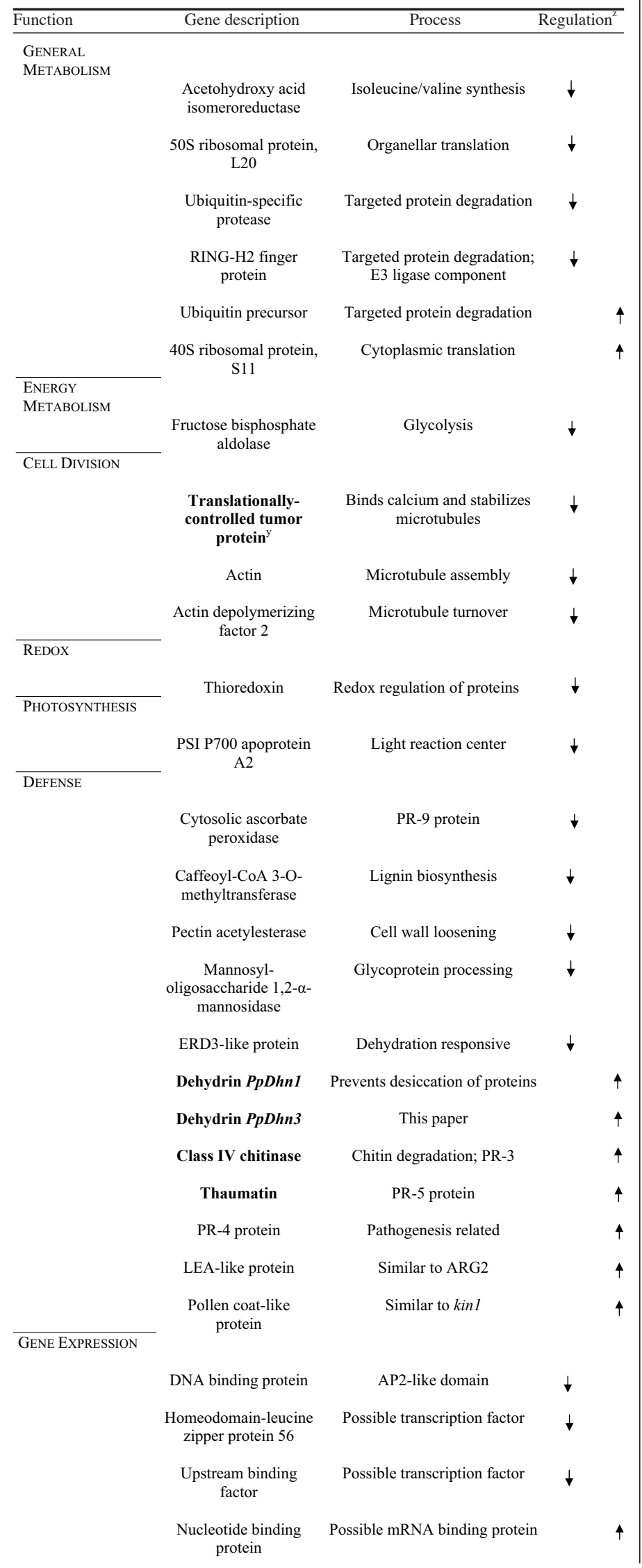

Table 5. Continued.

\begin{tabular}{llll}
\hline Function & Gene description & Process & Regulation $^{2}$ \\
\hline
\end{tabular}

MisCELLANEOUS

$\begin{array}{cl}\begin{array}{c}\text { Putative splicing } \\ \text { factor }\end{array} & \text { mRNA processing } \\ \begin{array}{c}\text { ADP-ribosylation } \\ \text { factor }\end{array} & \text { Vesicular trafficking } \\ \begin{array}{c}\text { Gibberellin-induced } \\ \text { protein }\end{array} & \text { Hormone responses } \\ \begin{array}{c}\text { Putative permease } \\ \text { Phloem-specific } \\ \text { protein }\end{array} & \text { Membrane transport }\end{array}$

$\begin{array}{cc}\begin{array}{c}\text { Rubber elongation } \\ \text { factor-related }\end{array} & \text { Latex particle protein } \\ \text { ORF 2 } & \text { Nodulin-like protein }\end{array}$

Phase-change protein Developmentally regulated

Transducin-like Associated with signaling protein

UNKNOWN

FUNCTION

$\begin{array}{lc}\begin{array}{c}\text { Putative senescence } \\ \text { protein }\end{array} & \text { Aging } \\ \text { Hypothetical protein } & \text { Has DNA binding motif } \\ \text { Hypothetical protein } & \text { Has zinc-finger motif } \\ \text { Hypothetical protein } & \text { Chloroplast protein } \\ \text { At1g22400 } & \downarrow \\ \text { homologue } & \downarrow \\ \text { At4g31410 } & \\ \text { homologue } & \\ \text { At4g18400 } & \\ \text { homologue } & \\ \text { At1g69230 } & \\ \text { homologue } & \\ \text { At3g21550 } & \\ \text { homologue } & \\ \text { At4g31410 } & \\ \text { homologue } & \\ \text { Unknown proteins } & \\ \text { Groups } 2,5,6 \text { and } 7 & \\ \text { At3g17380 } & \\ \text { homown proteins } 29-36 & \\ \text { At3g62130 } & \\ \text { homologue } & \\ \text { At5g17460 } & \end{array}$

${ }^{\mathrm{z}} \mathrm{Up}$-facing arrows indicate sequences up-regulated in response to low temperature; down facing arrows indicate sequences down-regulated in response to low temperature.

${ }^{\mathrm{y}}$ Bolded sequences are regulated the same way in both $5^{\circ} \mathrm{C}$ (A and E) subtractions; the remaining sequences were unique to either the $\mathrm{A}$ or $\mathrm{E}$ subtraction.

Sequences regulated by cold and photoperiod (A or E and B or C; shown in Fig. 4) were removed. 
Table 6. Summary of peach bark sequences regulated predominantly by short days (from the B and C subtractions).

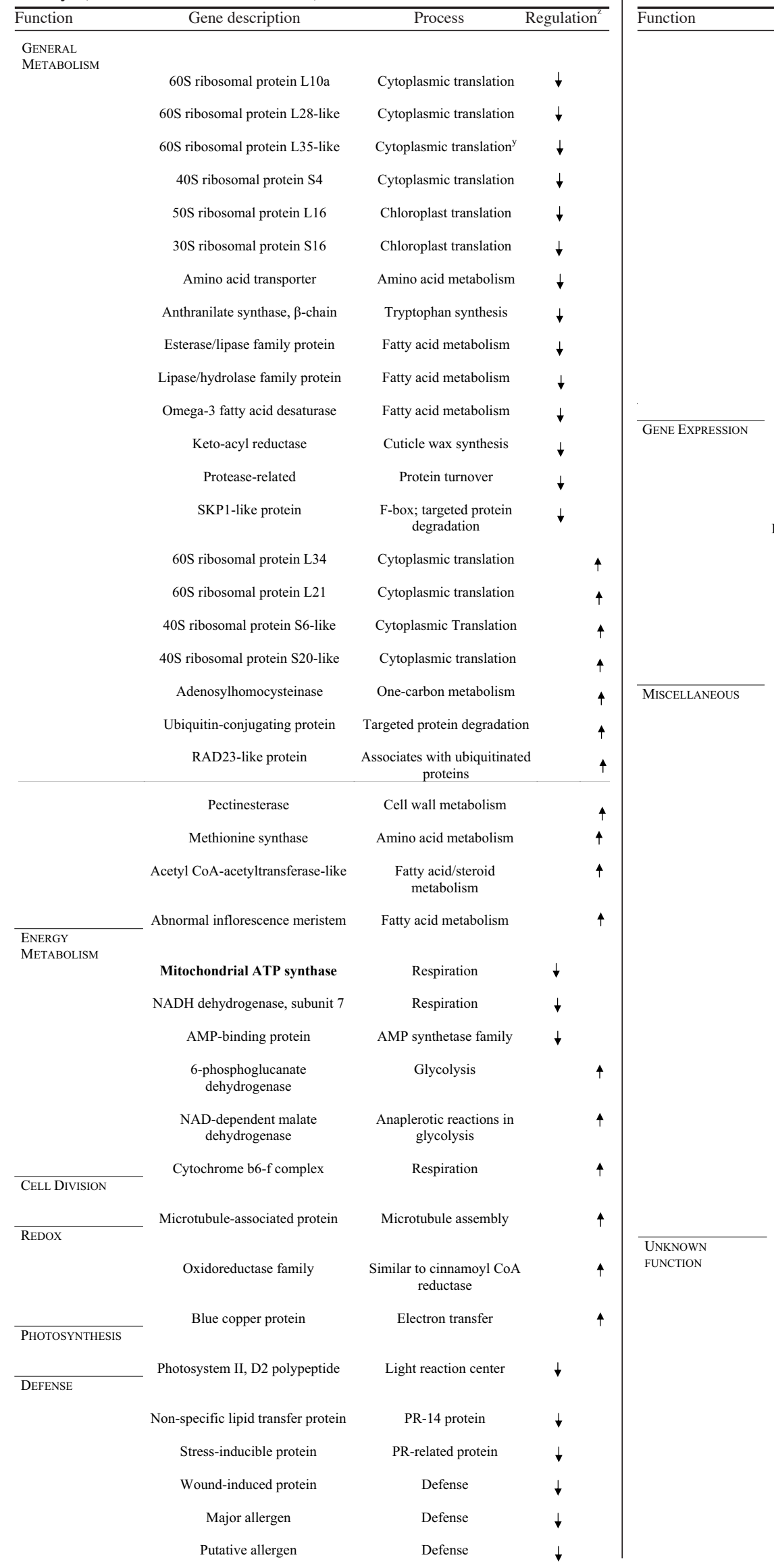

Table 6. Continued.

Gene description
Xyloglucanase inhibitor
$\beta$-amylase
$\beta$-cyanoalanine synthetase
LEA homologue
Dehydration-responsive protein
Chalcone synthase
Hsp 82
DnaJ protein

LMW heat shock protein

$$
\text { PRU allergen }
$$

Class II Chitinase

Putative extensin

Putative transcription factor

Putative transcription factor Putative chloroplast RNA-binding
protein

Myb-like protein

Zinc-finger protein

Homeodomain protein

Nucleic acid binding protein

Phosphatase 1

Calmodulin-binding protein

14-3-3-like protein

Synptobrevin-related protein

C2 domain protein

Auxin efflux carrier protein

Senescence-associated protein

rRNA intron homing

endonuclease

Hydroxyproline-rich protein

PDR-like ABC transporter

SAM decarboxylase

SAM synthetase

Mitochondrial carrier protein

Casein kinase

Steroid-binding protein

Unknown transferase

At3g11780 homologue

At2g12905 homologue

At4g23630 homologue

At4g31130 homologue

At2g27280 homologue

Arabidopsis NP_187568

homologue

Rice AAP21410 homologue

$\begin{array}{cc}\text { Process } & \text { Regulation }^{2} \\ \text { Defense } & \downarrow \\ \text { Stress } & \downarrow \\ \text { Detoxification } & \downarrow \\ \text { Defense } & \downarrow\end{array}$

Stress

Defense

Heat shock response

Heat shock response

Heat shock response

Unknown

Defense

Cell wall protection

Auxin-responsive

Contains AP2 domain

Salt inducible

Transcription

Transcription

Transcription

Has RNA recognition motif

$$
\text { Signaling }
$$

Signaling

Various processes via protein-protein interaction

Intracellular trafficking

Membrane trafficking

Auxin transport

Aging

Group I intron processing, usually organellar

Cell wall structure

Membrane trafficking

Spermine/spermidine synthesis

S-adenosylmethionine synthesis

Mitochondrial transport

Signaling

$\downarrow$
$\downarrow$
$\downarrow$
$\downarrow$
$\downarrow$
$\downarrow$
$\downarrow$
$\downarrow$
$\downarrow$

continued next page

J. AMER. SOC. HorT. SCI. 131(4):551-563. 2006. 
Table 6. Continued.

\begin{tabular}{|c|c|c|c|}
\hline Function & Gene description & Process & Regulation $^{2}$ \\
\hline & Rice CAE02140 homologue & & $\downarrow$ \\
\hline & Rice BAD07868 homologue & & $\downarrow$ \\
\hline & Rice NP_916003 homologue & & $\perp$ \\
\hline & Poplar AAO63778 homologue & & $\downarrow$ \\
\hline & $\begin{array}{l}\text { Unknown proteins } \\
\text { Groups } 8-16 ; 23 \text { and } 24\end{array}$ & & $\downarrow$ \\
\hline & UDP-glycosyltransferase family & & $\uparrow$ \\
\hline & Nif-U-like protein & & $\uparrow$ \\
\hline & At5g53880 homologue & & $\uparrow$ \\
\hline & At2g36485 & & $\uparrow$ \\
\hline & Rice NP_910689 & & $\uparrow$ \\
\hline & $\begin{array}{l}\text { Unknown proteins } \\
\text { Groups } 17-22 ; 25 \text { and } 26\end{array}$ & & $\uparrow$ \\
\hline
\end{tabular}

${ }^{2}$ Up-facing arrows indicate sequences up-regulated in response to short days; downfacing arrows indicate sequences down-regulated in response to short days. ${ }^{y}$ Wound-inducible.

lationally controlled tumor protein was originally described in mammals (Chipatima et al., 1988; Gross et al., 1989) and alfalfa (Medicago sativa L.; Pay et al., 1992), and is down-regulated by cold treatment. The other gene is a putative RNA-binding protein (RBP) gene that is a member of a rare and novel class of RBP proteins of unknown function. To our knowledge this particular class of RBPs has not been previously identified in other analyses of cold responsive gene expression.

One important difference in the present study compared with other global analyses of cold-regulated gene expression is the inclusion of treatments designed to separate SD responses from LT-specific responses. Cold acclimation in woody plants is thought to proceed in stages initiated by exposure to shorter photoperiods (Fuchigami et al., 1970; Weiser, 1970). Recent analysis of the expression of a silver birch (Betula pendula Roth.) dehydrin under LT and SD (12 h) photoperiods suggested that expression of LT-regulated genes is potentiated by short days to achieve maximum levels, since in LT under continuous light or in SD at higher temperatures expression was significantly lower (Puhakainen et al., 2004). Our results indicate that a number of stress-regulated genes, including some previously shown to be responsive to LT in other studies, are primarily regulated by photoperiod (Table 5). This result does not contradict conclusions reached in the birch study regarding the additive effects of SD and LT. Indeed, our libraries would not be able to ascertain the individual contributions of each treatment, but would reflect the dominant factor regulating expression at the time of RNA sampling. Therefore the expression of genes of interest would have to be examined in greater detail (e.g., more sampling times and treatment combinations) to assess more quantitatively the actual contribution of LT and photoperiod to overall expression, and it would not be surprising to find considerable variation in that contribution, since the number and quality of respective promoter response elements linked to cold and/or photoperiod are expected to differ among genes and gene family members. Furthermore, it is expected that some of these genes would be associated with different cold- and/or photoperiod-responsive pathways; there is ample evidence from the analysis of cold-responsive mutants in $A$. thaliana for the existence of multiple cold-responsive pathways (Shinozaki et al., 2003).

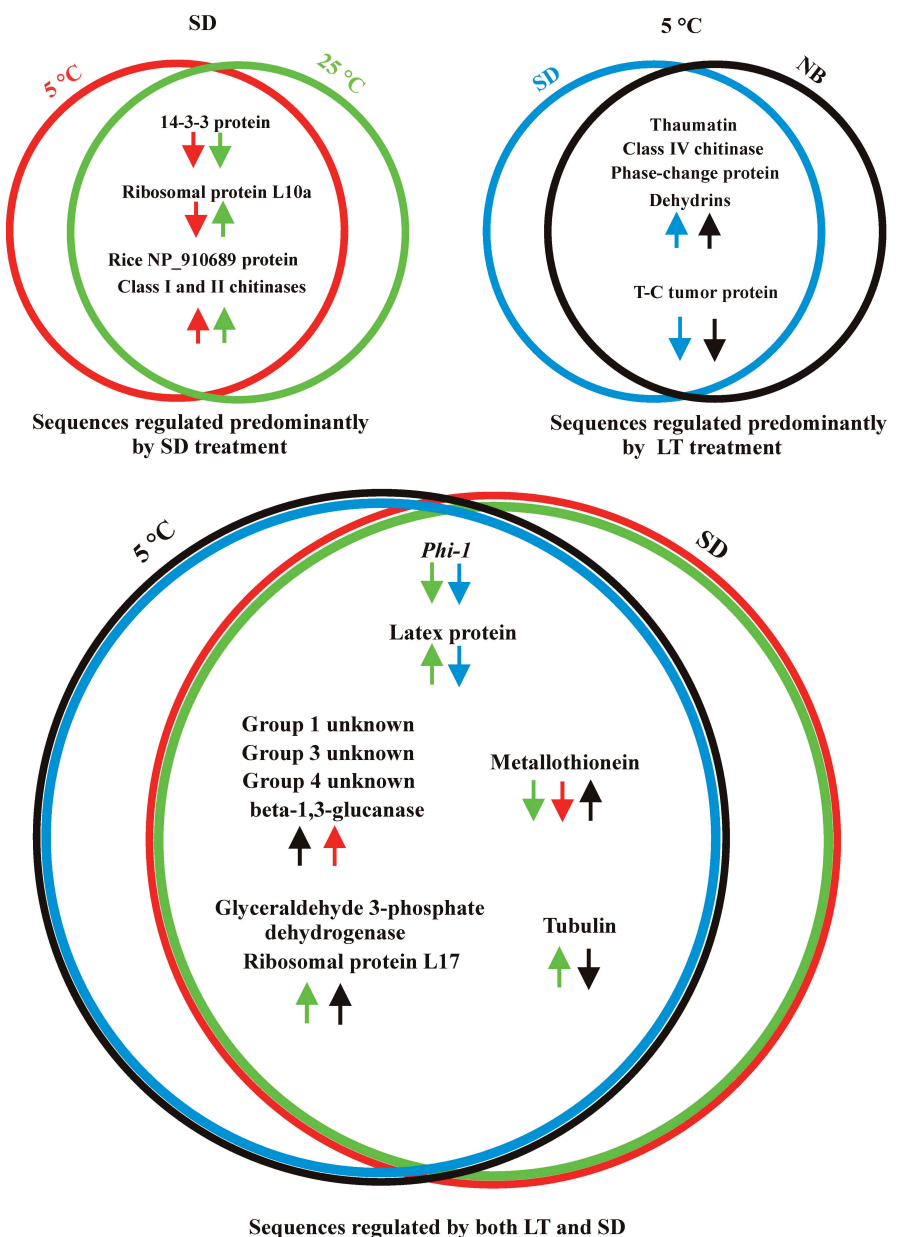

Fig. 4. Diagrammatic representation of peach sequences up- and down-regulated by low temperature $\left[\operatorname{LT}\left(5^{\circ} \mathrm{C}\right)\right]$ and/or short day photoperiods $[\operatorname{SD}(8 \mathrm{~h}$ light $/ 16$ $\mathrm{h}$ dark)]. BLAST and ClustalW analysis identified genes obtained from the subtracted cDNA combinations after PCR amplification, cloning and sequencing. The circles in the diagram represent the four subtracted combinations: black circles (AF and AR subtractions); blue circles (EF and ER subtractions), green circles (BF and $\mathrm{BR}$ subtractions), and red circles ( $\mathrm{CF}$ and $\mathrm{CR}$ subtractions). Arrows below the gene descriptors indicate the direction of change in expression reflected by the subtraction and are tinted to match the appropriate subtraction combination (circles). $\mathrm{NB}=$ night break $(15$ min light interrupting the $\mathrm{SD}$ dark period).

The efficacy of the subtractive combinations in selecting sequences expressed in an either/or state in response to treatments is quite extraordinary. This is supported by duplication of certain sequences in parallel treatments and by the high degree of separation maintained between each forward and reverse treatment. For example, out of more than 300 individual sequences analyzed, in only two cases were clones detected in a forward reaction also noted in the reverse reaction. Further analysis of both cases revealed that the clones represented a single gene or small gene family having significantly different $3^{\prime}$ untranslated regions and poly(A) attachment sites, which would have created single-stranded fragments in the first hybridization that would have appeared as "different" genes. Further support for the subtraction efficacy comes from PCR amplification of genes isolated from the various subtracted library combinations using the unsubtracted cDNAs templates, as illustrated in Figs. 2 and 3. Another feature of the methodology that sets it apart from other global approaches to differential gene expression is the ability to equalize the cDNA subtraction products so that low abundance 


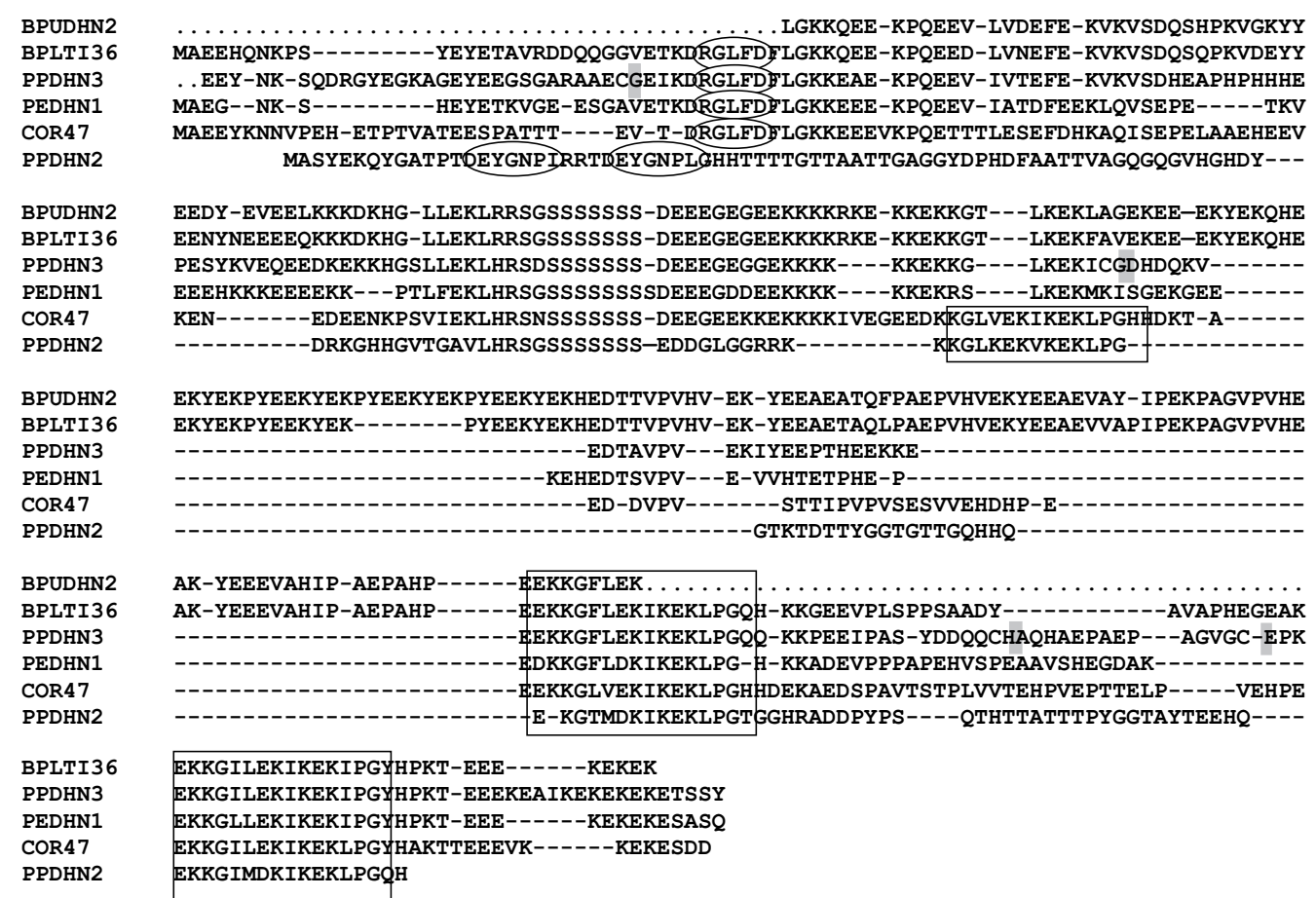

Fig. 5. Comparison of PPDHN3 amino acid sequence with dehydrins from diverse plants. Conceptual translations of genes representing dehydrins from different woody species and from A. thaliana were aligned with peach dehydrins using ClustalW. The alignment was manually adjusted to maximize similarity. PPDHN2 = peach dehydrin 2 (GenBank accession no. AY465376), PPDHN3 = peach dehydrin 3, which responds to low temperature [this paper (GenBank accession no. DQ111949)], BPUDHN2 is DHN2 from Betula pubescens (GenBank accession no. AJ555332), COR47 is a dehydrin from Arabidopsis thaliana (GenBank accession no. X59814), BPLTI36 is a low temperature-induced dehydrin from Betula pendula (Puhakainen et al., 2004), PEDHN1 is DHN1 from Populus $\times$ euroamericana (Dode) Guinier (GenBank accession no. Q9AR85). Y (DEYGNP) and D (DRGLF) segments are enclosed in ellipses, K (KIKEKLPG) segments are boxed. Cysteine residues in PPDHN3 are highlighted by grey boxes.

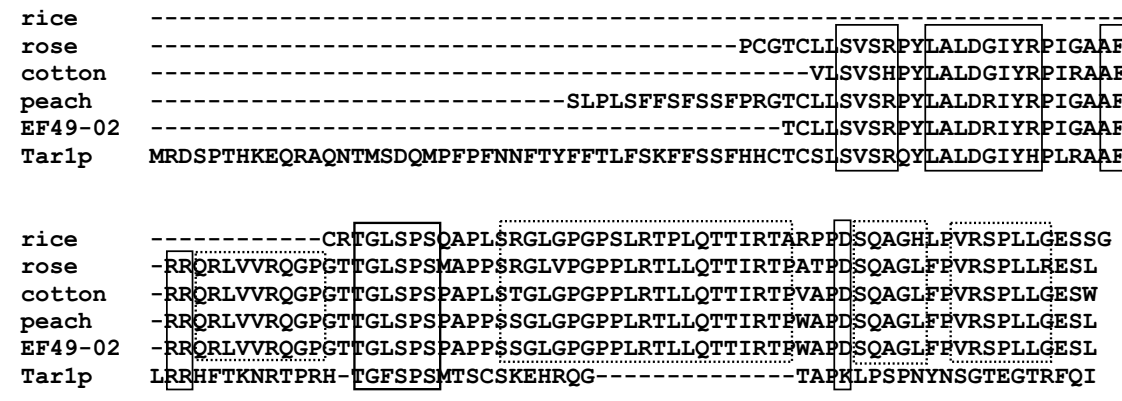

Fig. 6. Alignment of the low temperature up-regulated peach EF49-02 amino acid sequence with tar1p and tar1p-like proteins from different sources. Conceptual translation of genes representing TAR1-like sequences were aligned by ClustalW and refined by visual inspection. Solid line boxes highlight similarities between the yeast tarlp protein and predicted higher plant tar1p-like proteins; dotted line boxes highlight similarities among higher plant predicted tarlp-like proteins. Dashes represent gaps introduced to optimize the alignment. The rice polypeptide was predicted from a chromosomal sequence by NCBI's GenScan, but is presented here translated in a different frame (GenBank accession no. BAD07869). The rose (Rosa hybrida L. 'Fragrant Cloud') polypeptide was derived from a clone synthesized from RNA collected from immature (stage 4) flower petals (GenBank accession no. BQ105598). The cotton (Gossypium hirsutum L.) polypeptide was translated from a clone synthesized from RNA collected from fibers 7 to $10 \mathrm{~d}$ postanthesis (GenBank accession no. BE051999). The peach ('Fantasia') polypeptide was derived from RNA collected from young fruit $30 \mathrm{~d}$ after bloom (GenBank accession no. AJ873132). tar1p is from Saccharomyces cerevisiae (Meyen) Hansen (GenBank accession no. NP_690845). EF49-02 is a clone described in this study isolated from the E forward subtraction representing sequences up-regulated by low temperature.

RNAs are efficiently represented in each sample (Gurskaya et al., 1996). Finally, comparing the results of our subtracted analysis of LT treated bark tissues with a number of similar studies in both herbaceous and woody plants indicates that our results are in close agreement.

ANALYSIS OF SELECT GENES. Several novel genes up-regulated by LT treatment were identified in this study. BLASTx found a good match between clone EF49-02 and a hypothetical rice genomic sequence of unknown function. Interestingly, the program also found a short, but equally good match between the yeast $\operatorname{tar} 1 \mathrm{p}$ and a different EF49-02 translation frame. When the rice sequence was translated in all three frames, one of them matched both EF49-02 and tar1p. To further develop the identity of the EF49-02 clone, a BLASTn search of the "other EST" database revealed a number of dicot sequences that were similar to EF4902 , including a peach clone from a fruit library made from RNA obtained $30 \mathrm{~d}$ after bloom. Since the EST sequences represent partial clones, it remains to be seen whether the correct frame has been chosen; a full-length version of EF49-02 would resolve this question. If EF49-02 does, in fact, represent a woody plant homologue of TAR1, the fact that it is elevated at LT is intriguing. Although the function of yeast tar $1 \mathrm{p}$ is not fully understood, it has 


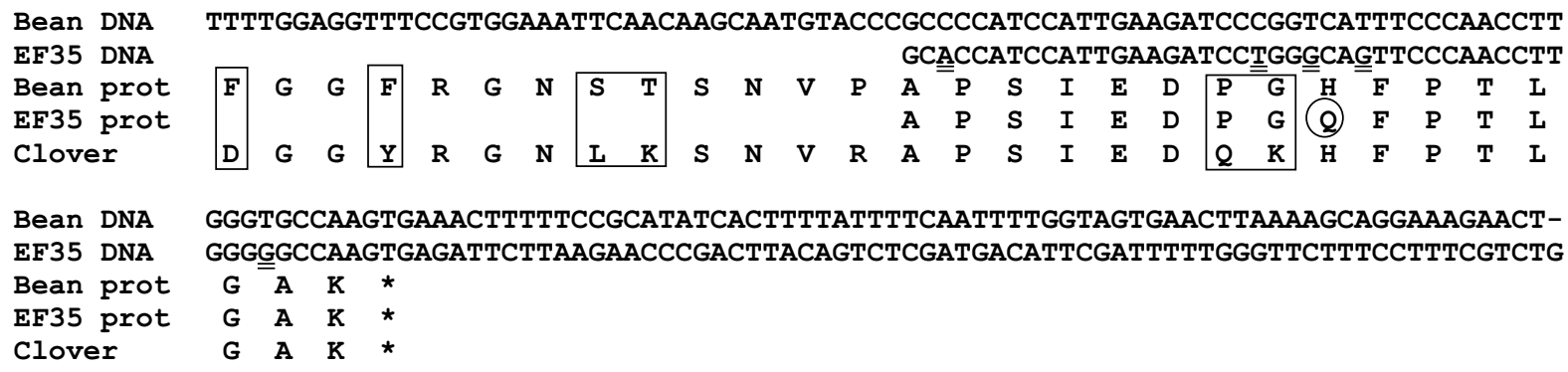

Bean DNA

ATGCTAATTTGTTCCTGTAATTTGATGTTTAAAGTGTAAATTTAGGTTCATACCATTGTTTATCCCTGATTGCTTT EF35 DNA ATGCAGGAAATTACTAGAATAATTGGATTTCCTGTATT-AАTTTTTTTTTTTTAAAAATTTATGACTTAAAATTGTA

Bean DNA GCСTTTATTGCTGTTGACATTTTCGGGGTAAACGGTGGTGGGTAAGAGTAAGACAAATGTTGTCGAGTTTTCTTTTCT EF35 DNA AАTTTCAGTTTCATATGTACССССTAGTAGTTTTTGTTTTCTTTTTTTСTTTTTCTATCCTTATGCAATGTTACTGAT

Bean DNA TTAAAAAAAAAAAAAAAAAAA EF35 DNA TTTCTGACTTTGGGGCATGTGAAAGGATTTATTCGTTACCAGATATAATCCTTGACAAGTTTTGTTTTCAAAAAAAAA

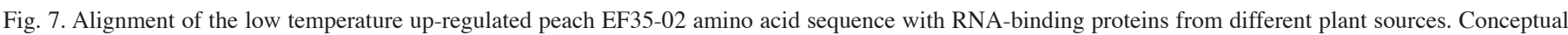

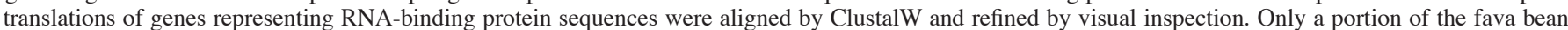

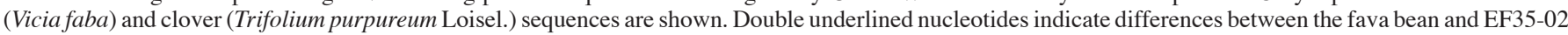

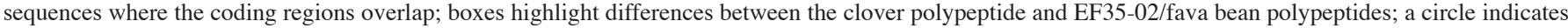

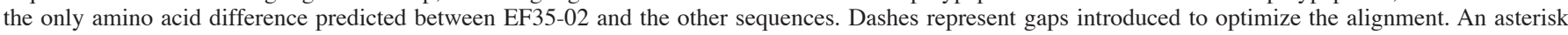
marks the termination codon. The fava bean polypeptide was derived from a gene deposited at NCBI (GenBank accession no. X97907). The clover sequence was derived from a gene deposited at NCBI (GenBank accession no. BG724469). EF35-02 is described in this study.

been observed to translocate to mitochondria and can suppress the petite phenotype of a point mutation in the mitochondrial RNA polymerase (Coelho et al., 2002). It is believed to coordinate rDNA transcription with mitochondrial function in response to changing cellular energy demands, such as one might expect to see under stress conditions.

EF35-02 appears to represent the 3'-most end of a gene encoding an RNA-binding protein. Recent studies indicate that many aspects of post-transcriptional processing and stability are regulated by a large number of RNA binding proteins and small RNAs which form stable ribonucleoprotein complexes. Although a number of RNA binding proteins have been identified in plants (Mar-Albe and Pagès, 1998), only a few have been associated with specific functions. Most of those isolated to date comprise a class of RNA binding proteins having a highly homologous RNA recognition motif (RRM) in the N-terminal region, and several of these proteins have been associated with stress responses, e.g., BLT 801, an LT-responsive gene from barley (Dunn et al., 1996), a maize (Zea mays L.) gene whose expression is enhanced by ABA in response to water deficit (Gómez et al., 1988), a gene from bread wheat (Triticum aestivum L.) that responds to cold treatment (Karlson et al., 2002), and a gene, atRZ-1a, from $A$. thaliana that can confer freezing tolerance when overexpressed (Kim et al., 2005). Recently, a novel group of plant RNA binding proteins lacking the RRM motif was identified from A. thaliana, tobacco (Nicotiana tabacum L.), and spinach (Spinacia oleracea L.) (Landsberger et al., 2002). Genes encoding these proteins appear to comprise small families with different expression patterns, but having bipartite nuclear localization sequences in common. If the full length EF35-02 RNA is actually a member of this new class of RNA-binding proteins, it will be the first report of such a gene responding to LT.

Dehydrins have long been associated with cold acclimation and water deficit stress. In A. thaliana there are 10 dehydrin or dehydrin-like genes possessing the K motif, and all show different patterns of expression in response to various stresses, in different tissues and at different times after exposure to stress. We have found two dehydrins in peach bark which differ in their seasonal expression patterns and in their response to cold and water deficit (Artlip et al., 1997; Wisniewski et al., 2006). We describe here the identification of a third dehydrin, PPDHN3, which has strong similarity to ERD10 and COR47. This dehydrin has a degenerate D-like domain, an $\mathrm{S}$ domain and two $\mathrm{K}$ segments. It is most closely related to birch and poplar dehydrins and compared to the A. thaliana dehydrin family, is more closely related to COR47 and the dehydrin at locus At4g38410 (data not shown), than to either of the previously described peach dehydrins. One unusual feature of PPDHN3, which bears mentioning, is the presence of four cysteine residues; with a few exceptions (Welling et al., 2004) most dehydrins lack cysteine. Analysis by programs that predict intramolecular cystine bridges did not find evidence for their existence in PPDHN3 (not shown); however, these programs do not rule out possible intermolecular interactions which might play a role in the function of these molecules.

Additional detailed analyses of the novel genes identified in this study will lead to a more complete understanding of how woody plants respond to different abiotic signals in their environment. Identifying the contributions made by various environmental signals will provide new information as to how different signaling pathways interact to control gene expression in response to abiotic stresses like LT. A more in-depth understanding of the regulation of genes induced and suppressed by various environmental signals could lead to new insights in developing trees better able to withstand those seasonal stresses encountered in temperate climates.

\section{Literature Cited}

Altschul, S.F., T.L. Madden, A.A. Schäffer, J.Zhang, Z.Zhang, W. Miller, and D.J. Lipman. 1997. Gapped BLAST and PSI-BLAST: A new generation of protein database search programs. Nucleic Acids Res. 25:3389-3402.

Arora, R., L.J. Rowland, J.S. Lehman, C-C. Lim, G.R. Panta, and N. Vorsa. 2000. Genetic analysis of freezing tolerance in blueberry (Vaccinium section Cyanococcus). Theor. Appl. Genet. 100:690-696.

Arora, R. and M.E. Wisniewski. 1994. Cold acclimation in genetically 
related (sibling) deciduous and evergreen peach (Prunus persica [L.] Batsch). II. A 60-kilodalton bark protein in cold-acclimated tissues of peach is heat stable and related to the dehydrin family of proteins. Plant Physiol. 105:95-101.

Artlip, T.S.,A.M. Callahan, C.L. Bassett, and M.E. Wisniewski. 1997. Seasonal expression of a dehydrin gene in sibling deciduous and evergreen genotypes of peach (Prunus persica [L.] Batsch). Plant Mol. Biol. 33:61-70.

Baker, S.S., K.S. Wilhelm, and M.F. Thomashow. 1994. The 5'-region of Arabidopsis thaliana cor 15 a has cis-acting elements that confer cold-, droughtand ABA-regulated gene expression. Plant Mol. Biol. 24:701-713.

Bliss, F.A., S. Anilsekar, M.R. Foolad, V. Becerra, A.M. Gillen, M.L. Warburton, A.M. Dandekar, G.M. Kocsisne, and K.K. Mydin. 2002. An expanded genetic linkage map of Prunus based on an interspecific cross between almond and peach. Genome 45:520-529.

Cai, Q., C.L. Guy, and G.A. Moore. 1994. Extension of the linkage map in Citrus using random amplified polymorphic DNA (RAPD) markers and RFLP mapping of cold-acclimation-responsive loci. Theor. Appl. Genet. 89:606-614.

Cai, Q., G.A.Moore, and C.L. Guy. 1995. An unusual group 2 LEAgene family in citrus responsive to low temperature. Plant Mol. Biol. 29:11-23.

Chipatima, S.T., S. Makrides, R. Bandyopadhya, and G. Brawerman. 1988. Nucleotide sequence of a major messenger RNA for a 21 kilo Dalton polypeptide that is under translational control in mouse tumor cell. Nucl. Acids Res. 16:2350-2353.

Close, T.J. 1996. Dehydrins: A commonality in the response of plants to dehydration and low temperature. Physiol. Plant. 100:291-296.

Coelho, P.S., A.C. Bryan, A. Kumar, G.S. Shadel, and M. Snyder. 2002. A novel mitochondrial protein, TAR1, is encoded on the antisense strand of the nuclear 25S rDNA. Genes Dev. 16:2755-2760.

Diatchenko, L., Y-F.C. Lau, A.P. Campbell, A. Chenchik, F. Moqadam, B. Huang, S. Lukyanov, K. Lukyanov, N. Gurskaya, E.D. Sverdlov, and P.D. Siebert. 1996. Suppression subtractive hybridization: A method for generating differentially regulated or tissue-specific cDNA probes and libraries. Proc. Natl. Acad. Sci. USA 93:6025-6030.

Dunn, M.A., K. Brown, R. Lightowlers, and M.A. Hughes. 1996. A lowtemperature-responsive gene from barley encodes a protein with singlestranded nucleic acid-binding activity which is phosphorylated in vitro. Plant Mol. Biol. 30:947-959.

Fowler, D.B., G. Breton, A.E. Limin, S. Mahfoozi, and F. Sarhan. 2001. Photoperiod and temperature interactions regulate low-temperature-induced gene expression in barley. Plant Physiol. 127:1676-1681.

Fowler, S. and M.F. Thomashow. 2002. Arabidopsis transcriptome profiling indicates that multiple regulatory pathways are activated during cold acclimation in addition to the CBF cold response pathway. Plant Cell 14:1675-1690.

Fuchigami, L.H., D.R. Evert, and C.J. Weiser. 1970. A translocatable cold hardiness promoter. Plant Physiol. 47:164-167.

Gómez, J.,D. Sánchez-Martinez, V. Stiefel, J. Rigau, P. Puigdomènech, and M. Pagès. 1988. A gene induced by the plant hormone abscisic acid in response to water stress encodes a glycine-rich protein. Nature 334:262-264.

Gong, Z., H. Lee, L. Xiong, A. Jagendorf, B. Stevenson, and J-K. Zhu. 2002. RNA helicase-like protein as an early regulator of transcription factors for plant chilling and freezing tolerance. Proc. Natl. Acad. Sci. USA 99:11507-11512.

Gross, B., M. Gaestel, H. Böhm, and H. Bielka. 1989. cDNA sequence coding for a translationally controlled human tumor protein. Nucl. Acids Res. 17:8367-8672.

Gurskaya, N.G., L. Diatchenko, A. Chenchik, P.D. Siebert, G.L. Khaspekov, K.A. Lukyanov, L.L. Vagner, O.D. Ermolaeva, S.A. Lukyanov, and E.D. Sverdlov. 1996. Equalizing cDNA subtraction based on selective suppression of polymerase chain reaction: Cloning of Jurkat cell transcripts induced by phytohemaglutinin and phorbol 12-myristate 13-acetate. Anal. Biochem. 240:90-97.

Howe, G.T., P.A. Bucciaglia, G.R. Furnier, W.P. Hackett, M.M. CordonnierPratt, and G. Gardner. 1998. Evidence that phytochrome gene family in black cottonwood has one PHYA locus and two PHYB loci but lacks members of the PHYC/F and PHYE subfamilies. Mol. Biol. Evol. 15:160-175.

Jung, S-H., J-Y. Lee, and D-H. Lee. 2003. Use of SAGE technology to reveal changes in gene expression in Arabidopsis leaves undergoing cold stress. Plant Mol. Biol. 52:553-567.

Kaplan, F. and C.L. Guy. 2004. $\beta$-amylase induction and the protective role of maltose during temperature shock. Plant Physiol. 135:1674-1684.
Karlson, D., K. Nakaminami, T. Toyomasu, and R. Imai. 2002. A cold-regulated nucleic acid-binding protein of winter wheat shares a domain with bacterial cold shock proteins. J. Biol. Chem. 277:35248-35256.

Karlson, D.T., Y. Zeng, V.E. Stirm, R.J. Joly, and E.N. Ashworth. 2003. Photoperiodic regulation of a $24-\mathrm{kD}$ dehydrin-like protein in red-osier dogwood (Cornus sericea L.) in relation to freeze-tolerance. Plant Cell Physiol. 44:25-34.

Kawamura, Y. and M. Uemura. 2003. Mass spectrometric approach for identifying putative plasma membrane proteins of Arabidopsis leaves associated with cold acclimation. Plant J. 36:141-154.

Kim, H-J., Y-K. Kim, J-Y. Park, and J. Kim. 2002. Light signaling mediated by phytochrome plays an important role in cold-induced gene expression through the C-repeat/dehydration responsive element (C/DRE) in Arabidopsis thaliana. Plant J. 29:693-704.

Kim, Y-O., Kim, J.S., and H. Kang. 2005. Cold-inducible zinc finger-containing glycine-rich RNA-binding protein contributes to the enhancement of freezing tolerance in Arabidopsis thaliana. Plant J. 42:890-900.

Kreps, J.A., Y. Wu, H-S. Chang, T. Zhu, X. Wang, and J.F. Harper. 2002. Transcriptome changes for arabidopsis in response to salt, osmotic and cold stress. Plant Physiol. 130:2129-2141.

Landsberger, M., Z.J. Lorković, and R. Oelmüller. 2002. Molecular characterization of nucleus-localized RNA-binding proteins from higher plants. Plant Mol. Biol. 48:413-421.

Lopez-Matas, M.A., P. Nuñez, A. Soto, I. Allona, R. Casado, C. Collada, M.A. Guevara, C. Aragoncillo, and L. Gomez. 2004. Protein cryoprotective activity of a cytosolic small heat shock protein that accumulates constitutively in chestnut stems and is up-regulated by low and high temperatures. Plant Physiol. 134:1708-1717.

Mar-Albe, M. and M. Pagès. 1998. Plant proteins containing the RNA-recognition motif. Trends Plant Sci. 3:15-21.

Marian, C.O., A. Eris, S.L. Krebs, and R. Arora. 2004. Environmental regulation of a $25 \mathrm{kDa}$ dehydrin in relation to Rhododendron cold acclimation. J. Amer. Soc. Hort. Sci. 129:354-359.

Muthalif, M.M. and L.J. Rowland. 1994. Identification of dehydrin-like proteins responsive to chilling in floral buds of blueberry (Vaccinium section Cyanococcus). Plant Physiol. 104:1439-1447.

Olsen, J.E. and O. Junttila. 2002. Far red end-of-day treatment restores wild type-like plant length in hybrid aspen overexpressing phytochrome A. Physiol. Plant. 115:448-457.

Pay, A., E. Heberle-Bors, and H. Hirt. 1992. An alfalfa cDNA encodes a protein with homology to translationally controlled human tumor protein. Plant Mol. Biol. 19:501-503.

Puhakainen, T., C. Li, M. Boije-Malm, J. Kangasjärvi, P. Heino, and E.T. Palva. 2004. Short-day potentiation of low temperature-induced gene expression of a C-repeat-binding factor-controlled gene during cold acclimation in silver birch. Plant Physiol. 136:4299-4307.

Rabbani, M.A., K. Maruyama, H. Abe, M.A. Khan, K. Katsura, Y. Ito, K. Yoshiwara, M. Seki, K. Shinozaki, and K. Yamaguchi-Shinozaki. 2003. Monitoring expression profiles of rice genes under cold, drought, and highsalinity stresses and abscisic acid application using cDNA microarray and RNA gel-blot analyses. Plant Physiol. 133:1755-1767.

Rinne, P., A. Welling, and P. Kaikuranta. 1998. Onset of freezing tolerance in birch (Betula pubescens) involves LEA proteins and osmoregulation and is impaired in an ABA-deficient genotype. Plant Cell Environ. 21:601-611.

Rinne, P., P. Kaikuranta, L.H. van der Plas, and C. van der Schoot. 1999. Dehydrins in cold-acclimated apices of birch: Production, localization and potential role in rescuing enzyme function during dehydration. Planta 103:753-761.

Sarnighausen, E., D. Karlson, and E. Ashworth. 2002. Seasonal regulation of a 24-kDa protein from red-osier dogwood (Cornus sericea) xylem. Tree Physiol. 22:423-430.

Schrader, S. and J.J. Sauter. 2002. Seasonal changes of sucrose-phosphate synthase and sucrose synthase activities in poplar wood (Populus $\times$ canadensis Moench 'robusta') and their possible role in carbohydrate metabolism. J. Plant Physiol. 159:833-843.

Seki, M., M. Narusaka, H. Abe, M. Kasuga, and K. Yamaguchi-Shinozaki. 2001. Monitoring the expression pattern of 1300 arabidopsis genes under drought and cold stresses using full-length cDNA microarray. Plant Cell 13:61-72.

Seki, M., M. Narusaka, J. Ishida, T. Nanjo, M. Fujita, Y. Oono, A. Kamiya, M. Nakajima, A. Enju, T. Sakurai, M. Satou, K. Akiyama, T. Taji, K. 
Yamaguchi-Shinozaki, P. Carninci, J. Kawai, Y. Hayashizaki, and K. Shinozaki. 2002. Monitoring the expression profiles of 7000 Arabidopsis genes under drought, cold and high-salinity stresses using a full-length cDNA microarray. Plant J. 31:279-292.

Shinozaki, K. and K. Yamaguchi-Shinozaki. 2000. Molecular responses to dehydration and low temperature: Differences and cross-talk between two stress signaling pathways. Curr. Opin. Plant Biol. 3:217-223.

Shinozaki, K., K. Yamaguchi-Shinozaki, and M. Seki. 2003. Regulatory network of gene expression in the drought and cold stress responses. Curr. Opin. Plant Biol. 6:410-417.

Smith, R.F., B.A. Wiese, M.K. Wojzynski, D.B. Davison, and K.C. Worley. 1996. BCM Search Launcher-An integrated interface to molecular biology data base search and analysis services available on the World Wide Web. Genome Res. 6:454-462.

Sterky, F., R.R. Bhalerao, P. Unneberg, B. Segerman, P. Nilsson, A.M. Brunner, L. Campaa, J. Jonsson-Lindvall, K. Tandre, S.H. Strauss, B. Sundberg, P. Gustafsson, M. Uhlen, R.P. Bhalerao, O. Nilsson, G. Sandberg, J. Karlsson, J. Lundeberg, and S. Jansson. 2004. A Populus EST resource for plant functional genomics. Proc. Natl. Acad. Sci. USA 101:13951-13956.

Stushnoff, C., M.J. Seufferheld, and T. Creegan. 1998. Oligosaccharides as endogenous cryoprotectants in woody plants, p. 301-309. In: P.H. Li and T.H.H. Chen (eds.). Plant cold hardiness: Molecular biology, biochemistry and physiology. Plenum Press, New York.

Thomashow, M.F. 1998. Role of cold-responsive genes in plant freezing tolerance. Plant Physiol. 118:1-7.

Ukaji, N., C. Kuwabara, D. Takezawa, K. Arakawa, S. Yoshida, and S. Fujikawa. 1999. Accumulation of small heat-shock protein homologs in the endoplasmic reticulum of cortical parenchyma cells in mulberry in association with seasonal cold acclimation. Plant Physiol. 120:481-490.

Ukaji, N., C. Kuwabara, D. Takezawa, K. Arakawa, and S. Fujikawa. 2001. Cold acclimation-induced WAP27 localized in endoplasmic reticulum in cortical parenchyma cells of mulberry tree was homologous to group 3 late-embryogenesis abundant proteins. Plant Physiol. 126:1588-1597.
Vertucci, C.W. and C. Stushnoff. 1992. The state of water in acclimating vegetative buds from Malus and Amelanchier and its relationship to winter hardiness. Physiologia Plantarum 86:503-511.

Wei, H., A.L. Dhanaraj, L.J. Rowland, Y. Fu, S.L. Krebs, and R. Arora. 2005. Comparative analysis of expressed sequence tags from cold-acclimated and non-acclimated leaves of Rhododendron catawbiense Michx. Planta 221:406-416.

Welling, A., P. Kaikuranta, and P. Rinne. 1997. Photoperiodic induction of dormancy and freezing tolerance in Betula pubescens: Involvement of ABA and dehydrins. Physiol. Plant 100:119-125.

Welling, A., T. Moritz, E.T. Palva, and O. Junttila. 2002. Independent activation of cold acclimation by low temperature and short photoperiod in hybrid aspen. Plant Physiol. 129:1633-1641.

Welling, A., P. Rinne, A. Viher-Aarnio, S. Kontunen-Soppela, P. Heino, and E.T. Palva. 2004. Photoperiod and temperature differentially regulate the expression of two dehydrin genes during overwintering of birch (Betula pubescens Ehrh.). J. Expt. Bot. 55:507-516.

Weiser, C.J. 1970. Cold resistance and injury in woody plants. Science 169:1269-1278.

Wisniewski, M.E., C.L. Bassett, T.S. Artlip, R.P. Webb, W.J. Janisiewicz, J.L. Norelli, M. Goldway, and S. Droby. 2003. Characterization of a defensin in bark and fruit tissues of peach and antimicrobial activity of a recombinant defensin in the yeast, Pichia pastoris. Physiologia Plantarum 119:563-569.

Wisniewski, M.E., C.L. Bassett, J. Renaut, R.E. Farrell, Jr., T. Tworkoski, and T.S. Artlip. 2006. Effect of photoperiod and temperature on expression of two dehydrin genes from peach (Prunus persica L Batsch.). Tree Physiol. 26:575-584.

Xin, Z. and J. Browse. 2000. Cold comfort farm: the acclimation of plants to freezing temperatures. Plant Cell and Environ. 23:893-902.

Zhu, B. and G.D. Coleman. 2001. Phytochrome-mediated photoperiod perception, shoot growth, glutamine, calcium, and protein phosphorylation influence the activity of the poplar bark storage protein gene promoter (bspA). Plant Physiol. 126:342-351. 